Fry, B. A. \& Gros, F. (1959). J. gen. Microbiol. 21, 685-692

\title{
The Metabolic Activities of Escherichia coli during the Establishment of Lysogeny
}

\author{
By B. A. FRY* AND F. GROS \\ Institut Pasteur, Paris
}

\begin{abstract}
SUMMARY: Escherichia coli strain K112 was infected with $\lambda$ phage (multiplicity of input 20 particles/cell) in $0.02 \mathrm{M}-\mathrm{MgSO}_{4}$, and $91 \%$ infected cells gave the lysogenic response. When the infected cells were transferred to a complete amino acid medium containing ${ }^{14} \mathrm{C}$-DL-phenylalanine and a non-utilizable inducer for $\beta$-galactosidase, the net synthesis of protein and nucleic acids did not begin until after 100-120 min. During this period there was no induced synthesis of $\beta$-galactosidase (though the enzyme was readily developed in uninfected cells) and there was no increase in turbidity of the culture or in viable cell count. The synthesis of protein and nucleic acids began in uninfected cells immediately they were placed in the complete medium, turbidity increased from the start and the viable count after $30 \mathrm{~min}$. This suggested that during lysogenization the infecting phage temporarily halts most if not all of the synthetic activities of the cell and thus forms an environment in which the phage genome can become attached to the bacterial chromosome and establish the prophage state.
\end{abstract}

The biochemical changes which occur after infection in a cell which is to become lysogenic have not been studied before in any detail. Whilst much attention has been given to the biochemical effects of infection of Escherichia coli by the $T$ phages, only a few experiments (cf. Lwoff, 1954-5) have been concerned with the effect of temperate phage on the metabolism of the host cell. The purpose of the present work was to attempt to study what determines the choice between the lytic and the lysogenic response, since the factors controlling this decision are not understood. At least in some bacteria, lysogeny is favoured by a high multiplicity of infection (Boyd, 1951), and after infection, changes in the environment, e.g. changes in temperature (Bertani \& Nice, 1954), or the presence of substances which prevent protein synthesis (Lwoff, Kaplan \& Ritz, 1954; Christensen, 1957) can alter the type of response. Conditions have been established for infecting virtually all the cells of a suspension of E. coli with $\lambda$ phage, and thus obtaining a population in which more than $90 \%$ of the infected cells give the lysogenic response. Some of the biochemical activities of these cells were examined and are reported here. A summary of these results has been given previously (Fry \& Gros, 1958).

\section{METHODS}

The organism, Escherichia coli strain K112, the preparation of washed cell suspensions and stock suspension of phage lambda $\left(\lambda_{22}\right)$, the composition of nutrient broth, the detection of response of infected cells and the determination of viable counts have been described previously (Fry, 1959).

* Present address: Department of Microbiology, University of Sheffield, England. 
Amino acid medium (CAA) consisted of $0.2 \%(\mathrm{w} / \mathrm{v}$ ) casamino acids (Difco) plus $0.004 \%(\mathrm{v} / \mathrm{v})$ nutrient broth at $\mathrm{pH} 7$.

Induction of $\beta$-galactosidase and estimation of activity. Iso-propylthiogalactoside (IPTG) was incorporated in medium CAA at a concn. of $10^{-3} \mathrm{M}$ : in the appropriate conditions, this substance can induce the synthesis of $\beta$-galactosidase, though it is not utilized by Escherichia coli, even in cells in which this enzyme has been induced (cf. Monod, Cohen-Bazire \& Cohn, 1951). Enzyme activity was determined directly in samples of the culture without separating the cells from the medium. A drop of toluene was added to a sample (1-2 ml.) of the culture, and the mixture incubated at $37^{\circ}$ for $30 \mathrm{~min}$. to make the enzyme (if present) accessible to the substrate (cf. Cohn \& Monod, 1951). An appropriate volume (0.05-1.5 ml.) of this enzyme preparation was mixed with $\mathrm{H}_{2} \mathrm{O}$ to $2 \mathrm{ml}$., and incubated in a standard $3 \mathrm{ml}$. Beckman cuvette at $2^{\circ}$ with $0.5 \mathrm{ml}$. 0.02 M-o-nitrophenyl-galactoside (Lederberg, 1950) in 0.5 M-Na phosphate buffer, $\mathrm{pH} 7$ containing $\mathrm{M}^{-\mathrm{MgSO}_{4}}$. The increase in absorption at $420 \mathrm{~m} \mu$. was followed at suitable intervals of time and enzyme activity is expressed in terms of the increase in absorption at $420 \mathrm{~m} \mu / \mathrm{ml}$. enzyme preparation/min.

Estimation of non-specific protein synthesis. Protein synthesis was followed in terms of the incorporation of ${ }^{14} \mathrm{C}$ from ${ }^{14} \mathrm{C}$-DL-phenylalanine into trichloroacetic acid (TCA) precipitable material freed from nucleic acids.

Preparation of samples and determination of protein, total nucleic acid, ribonucleic acid and deoxyribonucleic acid. Duplicate samples $(4 \mathrm{ml}$.) of the cultures were treated with $0.4 \mathrm{ml} .50 \%(\mathrm{w} / \mathrm{v})$ TCA. After standing overnight at $4^{\circ}$, the precipitates were collected by centrifugation at $4^{\circ}$ and washed once with $5 \%(w / v)$ TCA. The supernatants were rejected. Each precipitate was suspended in $0.5 \mathrm{ml} .5 \%(\mathrm{w} / \mathrm{v}) \mathrm{TCA}$ and heated at $100^{\circ}$ for $30 \mathrm{~min}$. in tubes capped with aluminium foil. The residue was collected by centrifugation and the supernatant separated carefully and kept for the determination of material absorbing at $260 \mathrm{~m} \mu$ (total nucleic acid), ribonucleic acid (RNA) and deoxyribonucleic acid (DNA). The residue was washed with $1 \mathrm{ml} .60 \%(\mathrm{v} / \mathrm{v})$ ethanol and then dissolved in $0.5 \mathrm{ml}$. $\mathrm{NH}_{4} \mathrm{OH}$ (1 part sp.gr. 880; 2 parts $\mathrm{H}_{2} \mathrm{O}$ ). Samples $(0.2 \mathrm{ml}$.) of the ammoniacal solution were spread and dried on metal planchets for the counting of ${ }^{14} \mathrm{C}$ at infinite thinness using a Geiger-Muller tube with an end window. Total nucleic acid was determined in terms of absorption at $260 \mathbf{m} \mu$ in samples of the hot TCA extract $(0.3 \mathrm{ml}$. extract from the cells of $4 \mathrm{ml}$. of the culture was diluted to $3 \mathrm{ml}$.: the blank cell contained $0.5 \%$ (w/v) TCA). For the estimation of DNA, samples of the hot TCA extract were diluted to $1 \mathrm{ml}$. and mixed with $0.2 \mathrm{ml} .3 \mathrm{~N}$-perchloric acid and $1.2 \mathrm{ml}$. Dische reagent (Burton, 1956). After $4 \mathrm{hr}$. at $37^{\circ}$ in a water bath, the absorption of the violet colour was measured at $590 \mathrm{~m} \mu$. A standard was prepared from a sample of sodium thymonucleate (Pointet \& Girard, Paris) previously heated with $5 \%(w / v)$ TCA and taken through the same procedure. For the estimation of RNA, $0.4 \mathrm{ml}$. of the hot TCA extract was mixed with $1.1 \mathrm{ml} . \mathrm{H}_{2} \mathrm{O}, 1.5 \mathrm{ml}$. $\mathrm{FeCl}_{3}(0 \cdot 1 \%, \mathrm{w} / \mathrm{v})$ in concn. $\mathrm{HCl}$ and $0.15 \mathrm{ml}$. orcinol $(10 \%, \mathrm{w} / \mathrm{v})$ in ethanol, and the mixture heated at $100^{\circ}$ for $40 \mathrm{~min}$. (Schneider, 1945). After cooling, 
the absorption of the green colour was determined at $650 \mathrm{~m} \mu$. The standard was sodium nucleate (Pointet \& Girard, Paris).

Measurements of turbidity of cultures and suspensions were made in a Meunier Spectrophotometer using the red filter. Where required, cultures were diluted until the cell concentration was in the range such that the apparatus gave a linear response to changes in turbidity.

Spectrophotometry. A Beckman DU Universal Spectrophotometer was used and cells with a light path of $1 \mathrm{~cm}$.

\section{Experimental procedure}

A culture of Escherichia coli strain K112 was grown in nutrient broth and harvested when it was about two-thirds of the way through the logarithmic phase of growth. A washed cell suspension $\left(2 \times 10^{8}\right.$ cells $/ \mathrm{ml}$.) was prepared, divided into two parts and warmed at $37^{\circ}$. One part was mixed with an equal prewarmed volume of $\lambda$ phage in $0.04 \mathrm{M}-\mathrm{MgSO}_{4}\left(4 \times 10^{9} \lambda / \mathrm{ml}\right.$.), giving a multiplicity of exposure of $20 \lambda /$ cell. The other part, the uninfected control cells, was mixed with an equal volume of prewarmed 0.04 M- $\mathrm{MgSO}_{4}$ alone. After $10 \mathrm{~min}$. at $37^{\circ}$, the cells were separated by centrifugation and resuspended in prewarmed medium CAA $\left(65 \mathrm{ml}\right.$.) containing ${ }^{14} \mathrm{C}$-DL-phenylalanine $\left(2 \times 10^{-4} \mathrm{M}\right.$, $20,000$ c.p.m. $/ \mu \mathrm{mole})$ and IPTG $\left(10^{-3} \mathrm{M}\right)$, the non-utilizable inducer for $\beta$-galactosidase. The two cultures of infected and uninfected cells were incubated at $37^{\circ}$ in $500 \mathrm{ml}$. conical flasks shaking gently in a water bath. Samples were taken at intervals for the determination of: (i) growth in terms of turbidity and viable cell count; (ii) protein synthesis in terms of the induced synthesis of $\beta$-galactosidase and the incorporation of ${ }^{14} \mathrm{C}$ into cell protein, and (iii) total nucleic acid, DNA and RNA by the analysis of hot TCA extracts of the cells. Furthermore, after the infected cells had been incubated for $10 \mathrm{~min}$., a sample was transferred to anti- $\lambda$ serum in broth and then plated in triplicate for the detection of the response of the infected cells (Fry, 1959). None of the cells were refractory, $9 \%$ gave the lytic response and $91 \%$ gave the lysogenic response, thus showing that the majority of the infected cells were cells in which lysogenization was to take place.

\section{RESULTS}

After being transferred to the casamino acid medium (CAA), the uninfected cells began to grow, and whilst turbidity increased logarithmically from the start, there was a lag of about $30 \mathrm{~min}$. before an increase in the viable cell count was detected, and after about $45 \mathrm{~min}$. the viable cell count was also increasing logarithmically (Fig. 1). These results are to be contrasted with those of the culture of infected cells, in which turbidity did not begin to increase until after $100 \mathrm{~min}$. and the viable count had just begun to increase after $145 \mathrm{~min}$. incubation (Fig. 1). Since most $(91 \%)$ of the infected cells were shown to give the lysogenic response, these results indicate that at least one of the metabolic activities which contribute to the synthesis of cell material is temporarily halted in cells in which the process of lysogenization is taking place and that this is 
revealed as a lag in the growth of a culture of these cells. The formation of $\beta$-galactosidase was not induced to any significant extent throughout the period of $190 \mathrm{~min}$. after infection (Fig. 2). In later experiments, with longer

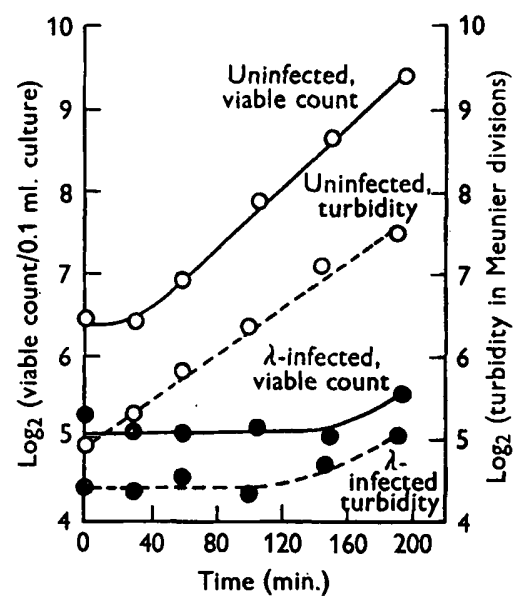

Fig. 1

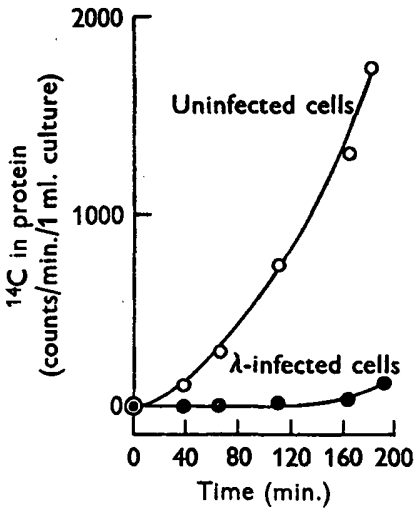

Fig. 3

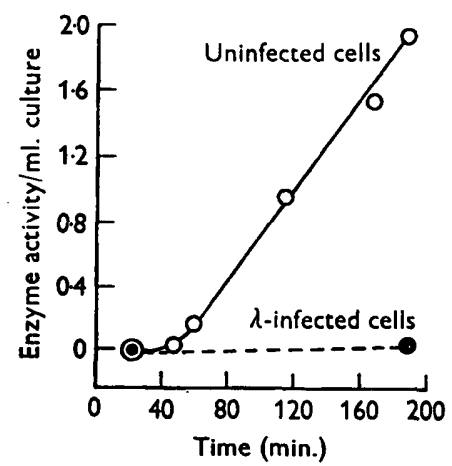

Fig. 2

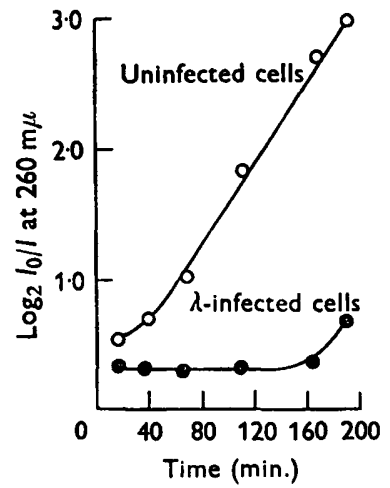

Fig. 4

Fig. 1. Growth of uninfected and $\lambda$-infected Escherichia coli strain K112. Cultures of uninfected and of $\lambda$-infected cells in medium CAA ( + IPTG $+{ }^{14} \mathrm{C}$-phenylalanine) incubated at $37^{\circ}$ and samples taken at intervals for determination of viable count and turbidity. In this and all other figures, time refers to period of incubation in medium CAA.

Fig. 2. Induction of $\beta$-galactosidase by isopropylthiogalactoside (IPTG) in uninfected and $\lambda$-infected Escherichia coli strain K112. $\beta$-galactosidase activity determined by the hydrolysis of $o$-nitrophenylgalactoside. Enzyme activity expressed as increase in absorption $\left(\log I_{0} / \mathrm{I}\right)$ at $420 \mathrm{~m} \mu / \mathrm{ml}$. of culture $/ \mathrm{min}$.

Fig. 3. Incorporation of ${ }^{14} \mathrm{C}$ from ${ }^{14} \mathrm{C}$-phenylalanine into the protein of uninfected and $\lambda$-infected Escherichia coli strain K112. After cells extracted with hot TCA, the residues were collected, washed with ethanol and dissolved in $\mathrm{NH}_{4} \mathrm{OH}$. Samples of the ammoniacal solution dried on metal planchets for determination of ${ }^{14} \mathrm{C}$.

Fig. 4. Synthesis of material absorbing at $260 \mathrm{~m} \mu$ (nucleic acids) in $\lambda$-infected and uninfected Escherichia coli strain K112. Hot TCA extracts of cells prepared and absorption measured at $260 \mathrm{~m} \mu$. Extracts diluted when required and absorption value multiplied by appropriate dilution factor. 
incubation periods, it was found that $\beta$-galactosidase activity was developed once the culture was growing at a rate comparable with that of the uninfected cells. In the culture of uninfected cells, the induction of $\beta$-galactosidase took place readily after the cells had been in the growth medium for about $40 \mathrm{~min}$. The lag in the induction in the uninfected cells is probably to be accounted for in terms of the concentration of amino acids in the medium being high enough to cause some initial inhibition of the induction process (cf. Cohn \& Monod, 1953). It would therefore appear that the protein synthesis is at least very much reduced in the $\lambda$-infected cells, and this conclusion is supported by the finding that no incorporation of ${ }^{14} \mathrm{C}$ into the protein of these cells was detected until after $120 \mathrm{~min}$. incubation in the growth medium (Fig. 3). However, in the uninfected cells, the incorporation of ${ }^{14} \mathrm{C}$ into protein followed the course to be expected in a culture growing logarithmically (Fig. 3). Examination of the hot TCA extracts of the infected cells for total nucleic acid, measured in terms of absorption at $260 \mathrm{~m} \mu$., showed that there was no detectable increase in nucleic acid until after $140 \mathrm{~min}$., whereas the total nucleic acid content of the uninfected cells increased very rapidly (Fig. 4). Determinations of the separate nucleic acids showed that there was no apparent net synthesis of RNA or DNA in the infected cells until after 120-140 min. incubation, but in the uninfected cells, DNA and RNA synthesis proceeded logarithmically from the start (Fig. 5).

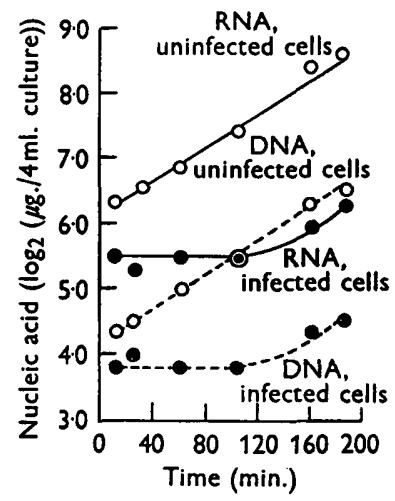

Fig. 5. Synthesis of RNA and DNA in uninfected and $\lambda$-infected cells of Escherichia coli strain K112. Hot TCA extracts of cells assayed for DNA and RNA (see Methods, p. 686).

\section{DISCUSSION}

From the results of the experiment described here, it appears that immediately after infection there is a profound disturbance in the metabolic activities of those cells in which the prophage of $\lambda$ is being established, and that the net synthesis of protein and nucleic acid is blocked for an appreciable time, and, although the cell remains viable, there is inevitably a delay in cell division. Previous workers (Bertani \& Nice, 1954; Lieb, 1953) have also noted this delay in division in cells giving the lysogenic response. Since the test for the 
response of the infected cells showed that $9 \%$ gave the lytic response, it may be asked why no synthesis of protein or nucleic acid was detected in the first $45 \mathrm{~min}$. (the normal latent period for $\lambda$ ) when the infected cells were incubated in the amino-acid medium. It is in fact possible that all the cells gave the lysogenic response when transferred to the liquid medium and that the response of a small proportion was changed towards the lytic response when they were plated on solid media $20 \mathrm{~min}$. after infection. It is well known that environmental changes can greatly affect the type of response to be elicited from infected cells (cf. Bertani, 1958), and it is feasible that manipulations involved in plating the bacteria in the response test may bring about such changes. Even if there was a small percentage of cells in which phage was maturing, it is possible that the experimental techniques were not sensitive enough to detect net synthesis on such a small scale. For example, DNA synthesis was not detected in Escherichia coli infected with $\mathrm{T}_{7}$, although the phage undoubtedly went into the vegetative state and multiplied (Kozloff, 1953). Whilst the possibility of some metabolic activity has not been excluded, the conclusion can be drawn from the results of the experiment reported here that the entry of phage material into the host cell either directly or indirectly blocks at least the majority of the synthetic reactions in those cells in which lysogenization is taking place. Though this belief is naive, it is not possible at the present time to elaborate it in detail and incorporate all the available experimental results into an unequivocal statement of what is happening during lysogenization.

Bertani \& Nice (1954) have found that Shigella dysenteriae can be turned from the lytic response towards lysogeny by taking $\mathbf{P} 1$-infected cells in complete medium at $37^{\circ}$ and placing them at a lower temperature $\left(24^{\circ}\right)$ for $2 \mathrm{hr}$.; this effect can be produced even at a comparatively late stage $(20 \mathrm{~min}$.) in the latent period (Bertani, 1953). With the Escherichia coli strain K12- $\lambda$ system studied by Lieb (1953), though raising the temperature from $37^{\circ}$ to $46^{\circ}$ appeared to promote the lytic rather than the lysogenic response, decreasing the temperature did not favour lysogeny. Stent \& Fuerst (1956), using $\lambda$ phage labelled with ${ }^{32} \mathrm{P}$, found only minor difference in the stabilization to decay of ${ }^{32} \mathrm{P}$ in cells of $\boldsymbol{E}$. coli giving the lytic response as compared with those giving the lysogenic response. Within $30 \mathrm{~min}$. after infection, the genome of the phage in cells being lysogenized was in a state such that it was no longer susceptible to the decay of ${ }^{32} \mathrm{P}$. Stent $\&$ Fuerst suggested that for a period immediately after infection, there was probably a common pathway for lysogeny and vegetative phage, and they deduced that little, if any, of the DNA of the invading phage becomes joined to the bacterial nuclear material to form the prophage. There is thus some indirect evidence that after infection the initial steps are the same irrespective of whether the cell is to give a lysogenic or a lytic response, and that an irrevocable decision as to the type of response is not made until some minutes after the infected cells have been placed in a complete medium. However, in bacteria infected with temperate phage and giving the lytic response the synthesis of protein and RNA still proceeds at rates comparable with those prior to infection, though DNA syn- 
thesis is stopped for several minutes (cf. Lwoff, 1954-5). But in the experiment reported here, dealing with cells undergoing lysogenization, there were no obvious signs of protein or RNA synthesis, indicating that relatively soon after infection the process of lysogenization is different from that leading to vegetative growth and the production of infective phage particles. It is well known from experiments with $E$. coli and the T phages that DNA and RNA synthesis is stopped immediately after infection, and that protein synthesis is restricted. Only after a certain amount of protein synthesis has occurred can DNA synthesis be resumed. Whether analogies should be sought between the effect of the $T$ phages and of $\lambda$ phage on the metabolism of $E$. coli is, however, doubtful, since there appears to be at least one fundamental difference between these two types of virus. The phage coats of the $\mathbf{T}$ viruses can themselves kill cells (Herriott, 1951; French \& Siminovitch, 1955), whereas such a lethal effect has not been demonstrated with phage coats of either wild type or virulent mutants of $\lambda$ (Weigle, quoted by Bertani, 1958).

In view of the striking reduction in the metabolic activities of cells during lysogenization, it is interesting to note that conditions which slow or inhibit metabolism, e.g. a reduction in temperature (Bertani \& Nice, 1954) or the presence of chloramphenicol (Christensen, 1957), appear to favour lysogeny. The significance of a high multiplicity of infection in lysogeny is not understood, but there is a suggestion that each phage particle can contribute something to inhibit the biochemical activity of the host cell and that if the multiplicity of infection is sufficiently high, these inhibitory effects are additive (cf. Hershey, 1955, 1957) and the activity of the host may thus be reduced so much that the end result is an environment in which the phage genome can become attached to the bacterial chromosome and not enter the vegetative phase of phage multiplication. If such a suggestion is correct, then it is feasible that if a cell is infected with only one particle, any artificial means of retarding the metabolic activity of the cell will also favour lysogenization. Evidence that the phage itself as well as the physiological condition of the host cell has something to contribute to the decision of lysogeny or phage production comes from the work of Levine (1955). Phage mutants which cannot themselves bring about lysogeny, can be brought into the prophage state if the cell is simultaneously infected with mutants of another but related type (which also by themselves are not capable of entering the prophage state). In other words, mixed infection led to lysogeny for what is usually called a 'virulent' phage, that is one capable of giving only the lytic response.

During the lag in the growth of the cells giving the lysogenic response, it is probable that the prophage is becoming established in the bacterial chromosome, and in order to determine how soon after infection this has been accomplished, various techniques can be exploited, e.g. sensitivity to ultraviolet light, the onset of immunity to infection by mutants of $\lambda$ and $T$ phages; and the ability to take part in bacterial recombination with the consequence of zygotic induction. It is hoped that the result of such experiments will contribute to an understanding of the process of lysogenization. 
This work was undertaken whilst one of us (B.A.F.) held a French Government Exchange Fellowship. We wish to express our sincere appreciation of the help and advice which we received from Dr A. Lwoff and Dr F. Jacob.

\section{REFERENCES}

Bertani, G. (1953). Lysogenic versis lytic cycle of phage multiplication. Cold Spr. Harb. Symp. quant. Biol. 18, 65.

Bertani, G. (1958). Lysogeny. Advanc. Virus Res. 5, 151.

Bertani, G. \& Nice, S. J. (1954). Studies on lysogenesis. 2. The effect of temperature on the lysogenisation of Shigella dysenteriae with phage P1. J. Bact. 67, 202.

Boyd, J. S. K. (1951). Excessive dose phenomenon in virus infection. Nature, Lond. 167, 1061.

Burton, K. (1956). A study of the conditions and mechanism of the diphenylamine reaction for the colorimetric estimation of deoxyribonucleic acid. Biochem. J. 62, 315.

Christensen, J. R. (1957). Effect of chloramphenicol on lysogenisation by temperate phage $\mathrm{P} 1$. Virology, 4, 184.

Conn, M. \& Monod, J. (1951). Purification et propriétés de la $\beta$-galactosidase (lactase) d'Escherichia coli. Biochim. biophys. Acta, 7, 153.

CoHn, M. \& Monod, J. (1953). Specific inhibition and induction of enzyme biosynthesis. In Adaptation in Micro-organisms. Ed. E. F. Gale and R. Davies. Symp. Soc. gen. Microbiol. 3, 132.

French, R. C. \& Siminovitch, L. (1955). The action of $T_{2}$ bacteriophage ghosts on Escherichia coli B. Canad. J. Microbiol. 1, 754.

Fry, B. A. (1959). Conditions for the establishment of lysogeny in Escherichia coli. J. gen. Microbiol. 21, 676.

Fry, B. A. \& Gros, F. (1958). The establishment of lysogeny in Escherichia coli. J. gen. Microbiol. 18, x.

Herriott, R. M. (1951). Nucleic-acid-free $T_{2}$ virus ghosts with specific biological action. J. Bact. 61, 752.

Hershey, A. D. (1955). The organisation of genetic material in bacteriophage $T_{2}$. In Mutation. Brookhaven Symp. Biol. 8, 6.

Hershey, A. D. (1957). Bacteriophages as genetic and biochemical systems. Advanc. Virus Res. 4, 25.

Kozloff, L. M. (1953). Origin and fate of bacteriophage material. Cold Spr. Harb. Symp. quant. Biol. 17, 207.

LEDERBERG, J. (1950). The $\beta$-D-galactosidase of Escherichia coli strain K 12. J. Bact. $60,381$.

Levine, M. (1955). The production of lysogeny for virulent bacteriophage by mixed infection. Genetics, 40, 582.

LIEB, M. (1953). The establishment of lysogenicity in Escherichia coli. J. Bact. 65, 642.

Lworf, A. (1954-5). Control and interrelations of metabolic and viral diseases of bacteria. Harvey Lect. 50.

Lwoff, A., Kaplan, A. S. \& Ritz, E. (1954). Research on the lysogenisation of Salmonella typhi-murium. Ann. Inst. Pasteur, 86, 127.

Monod, J., Cohen-Bazire, G. \& CoHN, M. (1951). Sur la biosynthèse de la $\beta$-galactosidase (lactase) chez Escherichia coli. La specificité de l'induction. Biochim. biophys. Acta, 7, 585.

Schneider, W. C. (1945). Phosphorus compounds in animal tissues. 1. Extraction and estimation of deoxypentose nucleic acid and of pentose nucleic acid. J. biol. Chem. 161, 293.

Stent, G. S. \& Fuerst, C. R. (1956). Decay of incorporated radioactive phosphorus during the development of a temperate bacteriophage. Virology, 2, 737. 